\title{
Pleural Fistula
}

National Cancer Institute

\section{Source}

National Cancer Institute. Pleural Fistula. NCI Thesaurus. Code C78560.

An abnormal communication between the pleural cavity and another anatomic site. 